\title{
Pressure effects on methane emissions from landfills
}

Kissas, Konstantinos; Scheutz, Charlotte; Kjeldsen, Peter; Ibrom, Andreas

Publication date:

2020

Document Version

Publisher's PDF, also known as Version of record

Link back to DTU Orbit

Citation (APA):

Kissas, K., Scheutz, C., Kjeldsen, P., \& Ibrom, A. (2020). Pressure effects on methane emissions from landfills. EGU2020-17746. Abstract from EGU General Assembly 2020.

https://meetingorganizer.copernicus.org/EGU2020/EGU2020-17746.html

\section{General rights}

Copyright and moral rights for the publications made accessible in the public portal are retained by the authors and/or other copyright owners and it is a condition of accessing publications that users recognise and abide by the legal requirements associated with these rights.

- Users may download and print one copy of any publication from the public portal for the purpose of private study or research.

- You may not further distribute the material or use it for any profit-making activity or commercial gain

- You may freely distribute the URL identifying the publication in the public portal

If you believe that this document breaches copyright please contact us providing details, and we will remove access to the work immediately and investigate your claim 
EGU2020-17746, updated on 24 Apr 2020

https://doi.org/10.5194/egusphere-egu2020-17746

EGU General Assembly 2020

(c) Author(s) 2020. This work is distributed under

the Creative Commons Attribution 4.0 License.

\section{Pressure effects on methane emissions from landfills}

Konstantinos Kissas, Charlotte Scheutz, Peter Kjeldsen, and Andreas Ibrom

Technical University of Denmark, Department of Environmental Engineering, Copenhagen, Denmark (konkis@env.dtu.dk)

Landfills are one of the major anthropogenic sources of methane $\left(\mathrm{CH}_{4}\right)$ emissions to the atmosphere, even years after being inactive. Model-based estimates of $\mathrm{CH}_{4}$ emission from landfills are inaccurate due to uncertainties in the underlying assumptions regarding gas generation rates, oxidation and recovery parameters. In-situ measurement techniques are more reliable in quantifying $\mathrm{CH}_{4}$ emissions, with the tracer gas dispersion method (TDM) being one of the bestvalidated methods. The TDM does however not allow for continuous estimation unless a higher sampling frequency for longer measurement campaigns is being used. Field studies report shortterm $\mathrm{CH}_{4}$ emission variation of several orders of magnitude, which are being driven by changes in meteorological conditions, with changes in barometric pressure being the most important. This variation makes discontinuous measurements more uncertain. In this presentation, we focus on $\mathrm{CH}_{4}$ emission dynamics under the influence of barometric pressure changes and develop a model that can explain the dynamics.

Landfill methane emissions were measured continuously with the eddy covariance method over several months in an inactive landfill (Skellingsted, Western Zealand, Denmark). The landfill is covered with an $80 \mathrm{~cm}$ thick soil layer and vegetated with grassland. Screenings of the site indicate a considerable horizontal heterogeneity of the emissions, which needs to be considered when interpreting continuously measured fluxes.

Measured methane fluxes ranged from 0 to $10 \mu \mathrm{mol} \nabla \mathrm{m}^{-2} \square \mathrm{s}^{-1}$. Periods with decreasing barometric pressure showed highest flux rates, while increasing barometric pressure suppressed the methane flux almost to $0 \mu \mathrm{mol} \square \mathrm{m}^{-2} \square \mathrm{s}^{-1}$. However, this dependency had a complex dynamic nature. In most of the cases, the responses of $\mathrm{CH}_{4}$ fluxes to pressure changes were delayed by 0 to 4 hours. We developed a model concept that is able to explain this behavior, including the pressure gradient driven advective $\mathrm{CH}_{4}$ transports through the porous soil layer above the source and diffusion between fronts of background air and landfill gas.

The general implications from this work are an estimation of the uncertainty and possibly correction of point $\mathrm{CH}_{4}$ emission measurements, e.g. with the TDM. Additionally, the increased understanding of gas transport dynamics through terrestrial landfill covers will help to evaluate the efficiency of methane emission mitigation methods that aim at increasing methane oxidation by the establishment of biocovers. 